\title{
Chiral Piperazines by Phosphoric Acid/Metal Nanoparticle Catalysis
}

\section{Gategory}

Polymer-Supported

Synthesis

Key words

gold catalysis

palladium catalysis platinum catalysis

aza-Friedel-Crafts reaction

benzylic alcohols

aminoethylpyrroles corporated polymer benzyl metacrylate AIBN (cat.) $\mathrm{PhMe}-\mathrm{H}_{2} \mathrm{O}(1: 2)$
$\mathrm{PVA}, 90^{\circ} \mathrm{C}, 12 \mathrm{~h}$

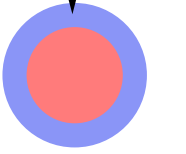

1 (Au/Pd NPs) $2(\mathrm{Au} / \mathrm{Pt} \mathrm{NPs})$ carcerated by polyme and carbon black<smiles>C=Cc1ccc(-c2ccc3c(C)c(OP(O)O)c(Br)cc3c2)cc1</smiles>

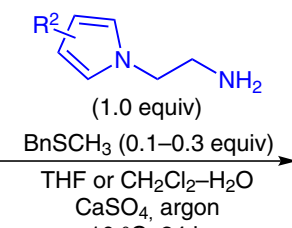<smiles></smiles>

(1.5 equiv) $\mathrm{O}_{2}(1 \mathrm{~atm})$

catalyst loading: 1 (1.5 mol\% Au, $1.4 \mathrm{~mol} \% \mathrm{Pd}, 5.2 \mathrm{~mol} \% \mathrm{P}$ ) 2 (3.0 mol\% Au, $4.8 \mathrm{~mol} \% \mathrm{Pt}, 8.8 \mathrm{~mol} \% \mathrm{P})$

Selected examples:<smiles>c1ccc(C2NCCn3cccc32)cc1</smiles>

$89 \%$ yield, $94 \%$ ee (with 1)<smiles>N#Cc1ccc(C2NCCn3cccc32)cc1</smiles>

$89 \%$ yield, $95 \%$ ee (with 2)

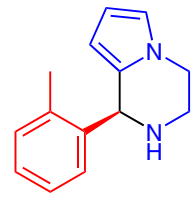

$91 \%$ yield, $92 \%$ ee (with 1)

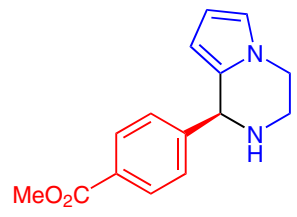

$84 \%$ yield, $90 \%$ ee (with 2)<smiles>COc1cccc(C2NCCn3cccc32)c1</smiles>

$83 \%$ yield, $93 \%$ ee (with 1)<smiles>Cc1ccc2n1CCN[C@H]2c1ccccc1</smiles>

$91 \%$ yield, $85 \%$ ee (with 1)<smiles>Fc1ccc([C@@H]2NCCn3cccc32)cc1</smiles>

$91 \%$ yield, $90 \%$ ee (with 2)

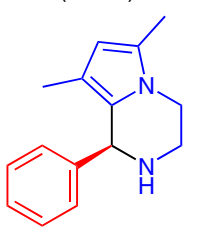

$83 \%$ yield, $70 \%$ ee (with 1)
Significance: Chiral phosphoric acids immobilized on polymer/carbon black-entrapped Au/Pd or Au/ Pt nanoparticles (1 and $\mathbf{2}$, respectively) were prepared according to eq. 1. Catalysts 1 and $\mathbf{2}$ promoted an aerobic oxidation of benzyl alcohols and subsequent asymmetric aza-Friedel-Crafts reaction with $\mathrm{N}$-(2-aminoethyl)pyrroles in one pot to give the corresponding chiral piperazines in $\leq 91 \%$ yield and $\leq 95 \%$ ee (eq. 2).

SYNFACTS Contributors: Yasuhiro Uozumi, Shun Ichii

Synfacts 2017, 13(05), 0545 Published online: 18.04.2017 Dol: 10.1055/s-0036-1590234; Reg-No.: Y04317SF
Comment: Benzyl methyl sulfide prevents oxidation of the resulting piperazine products to their imine forms. In the sequential reactions of benzyl alcohol and [2-(1H-pyrrol-1-yl)ethyl]amine, catalyst $\mathbf{1}$ was recovered by filtration and reused five times without significant loss of its catalytic performance (first run: 92\% yield, 89\% ee, sixth run: $85 \%$ yield, $84 \%$ ee). 